\title{
Cutaneous nodules in Irrawaddy dolphins: an emerging disease in vulnerable populations
}

\author{
Marie-Francoise Van Bressem ${ }^{1, *}$, Gianna Minton ${ }^{2,3}$, Dipani Sutaria ${ }^{4}$, \\ Nachiket Kelkar ${ }^{5}$, Cindy Peter ${ }^{2}$, Mohammad Zulkarnaen ${ }^{6}$, Rubaiyat M. Mansur ${ }^{7}$, \\ Lindsay Porter ${ }^{8}$, Luz H. Rodriguez Vargas ${ }^{9}$, Leela Rajamani ${ }^{9}$ \\ ${ }^{1}$ Cetacean Conservation Medicine Group (CMED), Centro Peruano de Estudios Cetológicos (CEPEC), Lima 20, Peru \\ ${ }^{2}$ Institute of Biodiversity and Environmental Conservation, Universiti Malaysia Sarawak, Kota Samarahan, \\ 94300 Sarawak, Malaysia \\ ${ }^{3}$ WWF Gabon, BP 9144, Libreville, Gabon \\ ${ }^{4}$ Adjunct Research Fellow, School of Earth and Environmental Sciences, James Cook University, Townsville, \\ Queensland 4811, Australia \\ ${ }^{5}$ Research Affiliate, Nature Conservation Foundation, 3076/5, IV Cross, Gokulam Park, Mysore, 570002 Karnataka, India \\ ${ }^{6}$ Department of Pathology, Universiti Malaysia Sarawak, Kuching, 93150 Sarawak, Malaysia \\ ${ }^{7}$ Bangladesh Cetacean Diversity Project, Wildlife Conservation Society, House \#89, Road \#2, Sonadanga R/A, Khulna 9000, \\ Bangladesh \\ ${ }^{8}$ The University of St. Andrews, New Technology Centre, North Haugh, St. Andrews, Fife, KY16 9SR Scotland, UK \\ ${ }^{9}$ Centre for Marine and Coastal Studies, Universiti Sains Malaysia, 11800 USM Pulau Pinang, Malaysia
}

\begin{abstract}
The presence of cutaneous nodules is reported in vulnerable populations of Irrawaddy dolphins Orcaella brevirostris from Malaysia (Kuching, Bintulu-Similajau, KinabatanganSegama and Penang Island), India (Chilika Lagoon) and Bangladesh (Sundarbans). Approximately 5700 images taken for photo-identification studies in 2004 to 2013 were examined for skin disorders. Nodules were detected in 6 populations. They appeared as circumscribed elevations of the skin and varied in size from 2 to $>30 \mathrm{~mm}$, were sparse or numerous and occurred on all visible body areas. In 8 photo-identified (PI) dolphins from India and Malaysia, the lesions remained stable $(\mathrm{N}=2)$ or progressed $(\mathrm{N}=6)$ over months but did not regress. The 2 most severely affected individuals were seen in Kuching and the Chilika Lagoon. Their fate is unknown. Cutaneous nodules were sampled in a female that died in a gillnet in Kuching in 2012. Histologically, the lesions consisted of thick collagen bundles covered by a moderately hyperplasic epithelium and were diagnosed as fibropapillomas. Whether the nodules observed in the other $O$. brevirostris were also fibropapillomas remains to be investigated. Disease prevalence ranged from $2.2 \%$ ( $\mathrm{N}=46$; Bintulu-Similajau) to $13.9 \%$ ( $\mathrm{N}=72$; Chilika) in 4 populations from Malaysia and India. It was not significantly different in 3 study areas in eastern Malaysia. In Chilika, prevalence was significantly higher ( $\mathrm{p}=0.00078)$ in 2009 to $2011(13.9 \%)$ than in 2004 to $2006(2.8 \%)$ in 72 PI dolphins. The emergence of a novel disease in vulnerable $O$. brevirostris populations is of concern.
\end{abstract}

KEY WORDS: Irrawaddy dolphin - Orcaella brevirostris - Malaysia - India - Bangladesh · Epidemiology $\cdot$ Fibropapillomas $\cdot$ Skin disease $\cdot$ Cutaneous nodules $\cdot$ Conservation

Resale or republication not permitted without written consent of the publisher

\section{INTRODUCTION}

In recent years emerging infectious diseases have been frequently reported in several cetacean species and populations worldwide, provoking large-scale die-offs, affecting reproduction and causing disfiguring skin lesions (Gulland \& Hall 2007, Van Bressem et al. 2009a). Cutaneous nodular and granulomatous syndromes have been increasingly observed in odontocetes, in particular over the past 2 decades (Cald- 
well et al. 1975, Kiszka et al. 2009, Reif et al. 2009, Van Bressem et al. 2009b, 2013). In some small communities of inshore and estuarine populations, these pathologies are highly prevalent, may progress to cover extensive body areas and have been associated with the death or disappearance of severely affected individuals, including calves (Simões-Lopes et al. 1993, Bossart et al. 2003, Van Bressem et al. 2007a, 2013, Kiszka et al. 2009, Daura-Jorge \& SimõesLopes 2011). However, their impact on the long-term viability of affected communities is still vastly unknown. The fungi Lacazia loboi, Fusarium spp., Paracoccidioides brasiliensis and Trichophyton spp. have been identified as the aetiological agents of some nodular disorders (Caldwell et al. 1975, Frasca et al. 1996, Van Bressem et al. 2007a, Esperón et al. 2012, Tanaka et al. 2012). Immune dysfunction is also known to play a role in the pathogenesis of L. loboi disease in coastal common bottlenose dolphins Tursiops truncatus from Florida, USA (Reif et al. 2009, Murdoch et al. 2010).

Irrawaddy dolphins Orcaella brevirostris occur in large rivers and marine appended lakes in South Asia, as well as in the coastal waters of the Indo-Pacific Ocean (Smith 2009). Estuarine and nearshore populations are distributed in tropical and subtropical waters of the Indo-Pacific Ocean, from eastern India to the Philippines (Dolar et al. 2002, Smith et al. 2006, Minton et al. 2011). Riverine populations have been documented in 3 major river systems: the Mahakam (Indonesia), the Ayeyarwady (Myanmar) and the Mekong (Laos, Cambodia and Vietnam) (Smith 2009). Their habitat preference exposes them to multiple anthropogenic threats, including gillnet entanglement, boat traffic, habitat loss and degradation and pollution (Jefferson et al. 2000, Dolar et al. 2002, Reeves et al. 2003, Baird \& Beasley 2005, Smith et al. 2008, Van Waerebeek et al. 2008, Sutaria 2009). The species is classified as 'Vulnerable' in the IUCN Red List. However, the 3 riverine populations and those from Songkhla Lake and the Malampaya Sound, Philippines, have been listed as 'Critically Endangered' (IUCN 2008). Any source of enhanced morbidity and mortality or a reduction in reproductive capacity is therefore of concern for their conservation.

During the course of photo-identification studies in Sarawak, Malaysia, and in Chilika Lagoon, India, several skin nodules were observed in 2 Orcaella brevirostris. This prompted us to examine the macroand microscopic features of this condition as well as its epidemiological characteristics in O. brevirostris populations from Malaysia, India and Bangladesh using images taken for photo-identification studies in
2004 to 2013, as described by Thompson \& Hammond (1992). During this study one of the photoidentified (PI) dolphins from Sarawak, positive for cutaneous nodules, died following accidental gillnet entanglement, and was sampled in an attempt to elucidate the aetiology of the disease. Here we report on our findings.

\section{MATERIALS AND METHODS}

\section{Photo-identification surveys and study areas}

The photo-identification surveys were realized in Bangladesh, Malaysia and India between 2004 and 2013 (Table 1) following the methods described in Smith et al. (2006), Minton et al. (2011, 2013) and Sutaria \& Marsh (2011). Dolphins were photographed with digital SLR cameras equipped with 70 to $400 \mathrm{~mm}$ zoom lenses, at distances ranging from a few to several hundreds of meters. Individuals were identified using natural marks on the dorsal fin (Würsig \& Jefferson 1990).

Malaysia

Images were analysed from 4 separate study sites (Kuching, Bintulu-Similajau, Kinabatangan-Segama river basin and Penang Island), 400 to $1500 \mathrm{~km}$ distant from each other (Fig. 1). Kuching and BintuluSimilajau, in Sarawak State, were surveyed between February and October in 2008 to 2011, to avoid the monsoon season (November through January). The Kuching coastline is bounded roughly by $110^{\circ} 13^{\prime}$ to $110^{\circ} 50^{\prime} \mathrm{E}$ and $1^{\circ} 65^{\prime}$ to $1^{\circ} 82^{\prime} \mathrm{N}$. It comprises complex and interconnected series of wide rivers and mangrove channels, which empty into 3 major estuaries (Minton et al. 2011). The Similajau study area follows a $15 \mathrm{~km}$ wide coastal strip centred at about $113^{\circ} 00^{\prime} \mathrm{E}$ and running from approximately $3^{\circ} 30^{\prime}$ to $3^{\circ} 80^{\prime} \mathrm{N}$. It is interspersed with rivers and streams of varying sizes. The Kinabatangan-Segama study site is located in Sabah, Malaysia's eastern seaboard, and is bounded by $5^{\circ} 25^{\prime}$ to $5^{\circ} 50^{\prime} \mathrm{N}$ and $118^{\circ} 15^{\prime}$ to $118^{\circ} 55^{\prime} \mathrm{E}$. This site, which lies in an internationally protected and largely undisturbed wetland area containing mangrove and rare peat swamp forest, was surveyed throughout 2011. Bounded to the north by $5^{\circ} 28^{\prime} \mathrm{N}$, $100^{\circ} 12^{\prime} \mathrm{E}$ and to the west by $5^{\circ} 29^{\prime} \mathrm{N}, 100^{\circ} 16^{\prime} \mathrm{E}$, the Penang study area receives freshwater input from the Pinang and Burung Rivers. Surveys commenced here in early 2013. 
Table 1. Orcaella brevirostris. Characteristics of cutaneous fibropapillomas and nodules in O. brevirostris from 3 range states over various periods. No. of PI dolphins: number of photo-identified dolphins examined for skin nodules; LDF: left dorsal fin; RDF: right dorsal fin; NA: data not available; Unk.: unknown

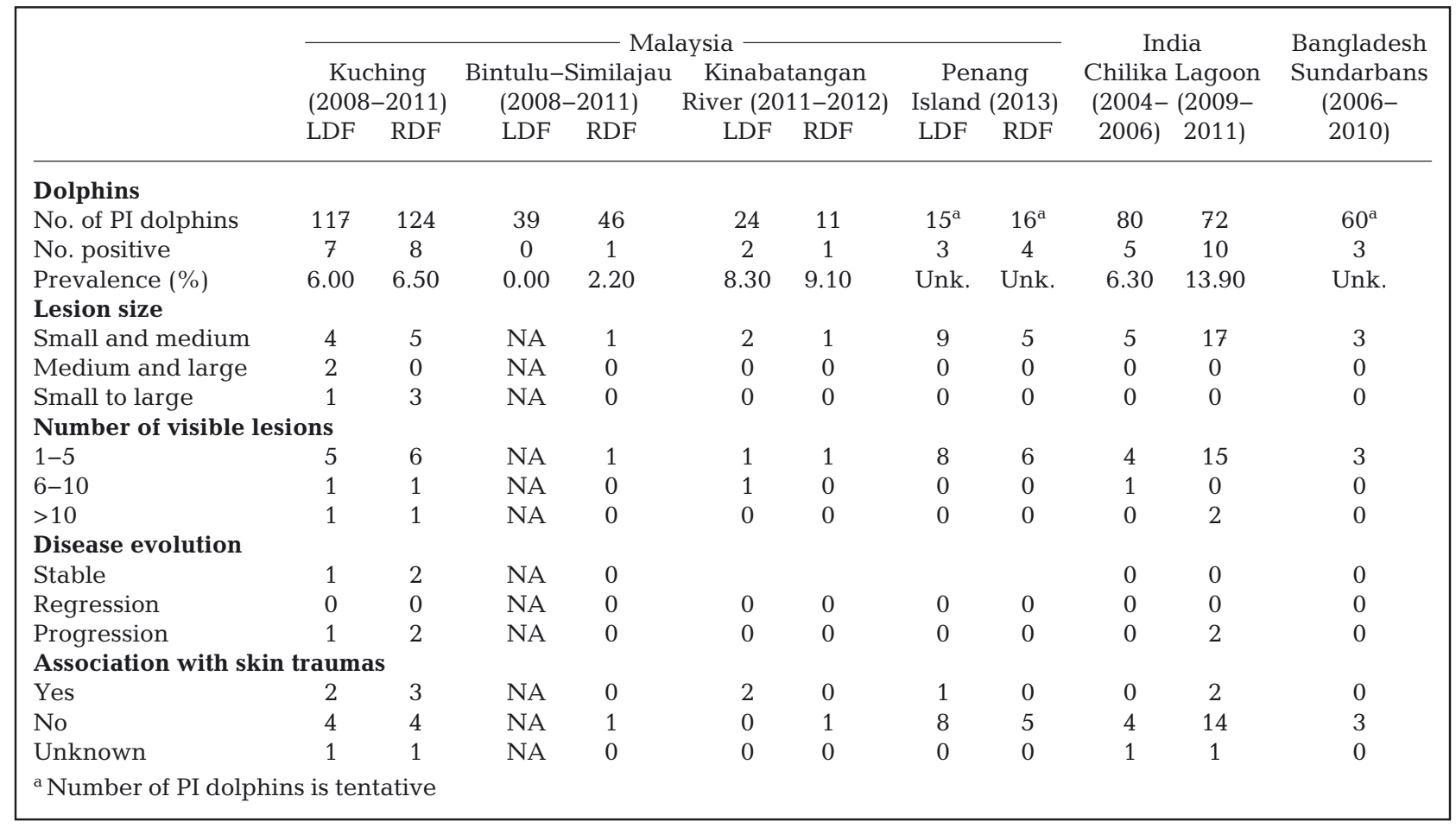

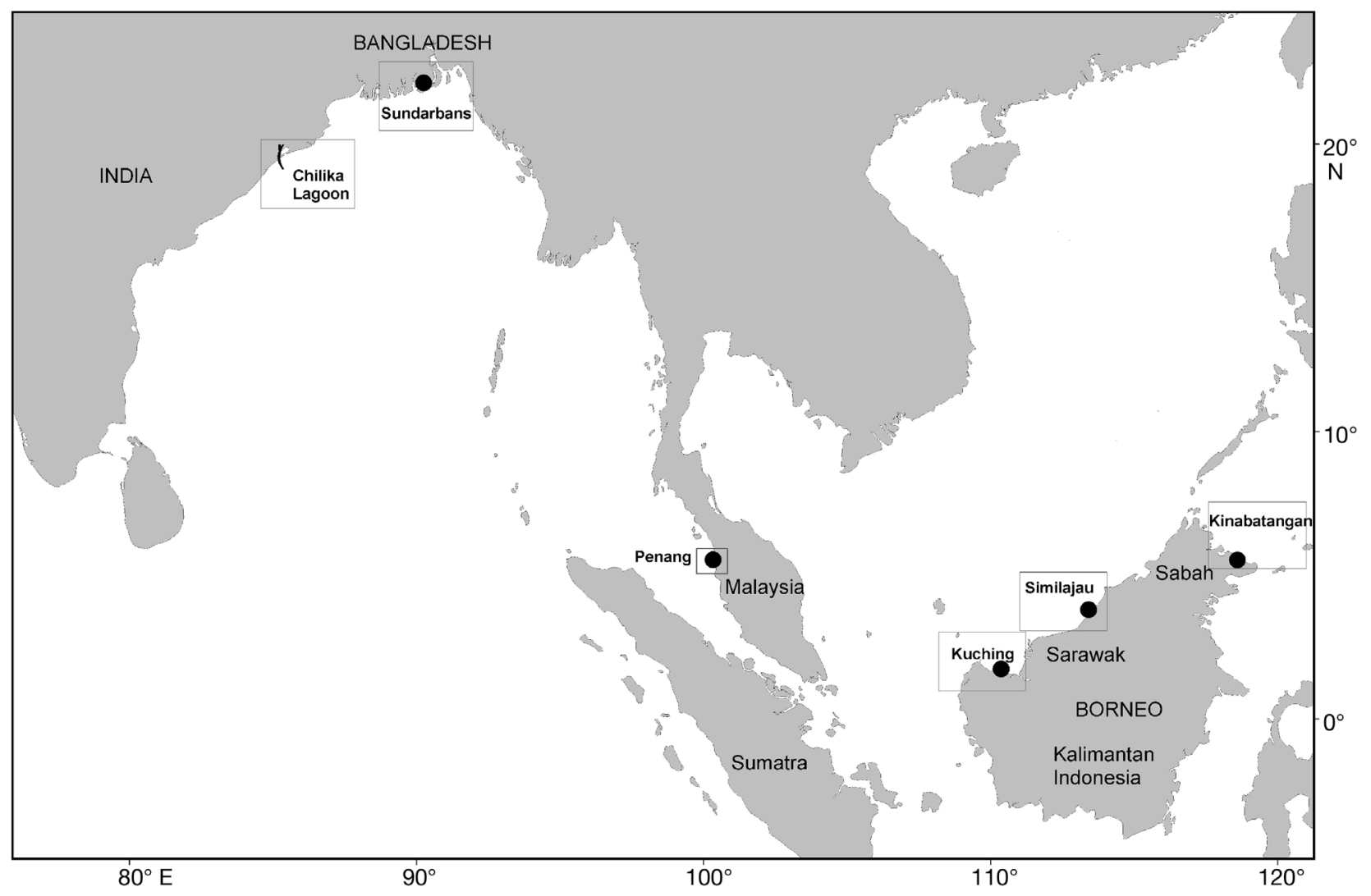

Fig. 1. Locations of the study areas in Malaysia, India and Bangladesh 
In Penang, Kuching and Bintulu-Similajau images of the left (LDF) and right (RDF) sides of dorsal fins were treated as 2 separate datasets, and assigned separate sequences of individual identification (ID) numbers because, with the exception of severely disfigured individuals, it was not possible to match RDF and LDF accurately. As such, individual dolphins may have 2 separate ID numbers. In the Kinabatangan-Segama study site, LDF and RDF were matched when possible. On the basis of high site fidelity, large distances between the survey sites and of biological information for other Orcaella brevirostris populations, dolphins photographed in Kuching, BintuluSimilajau and Sabah were considered as different sub-populations and analysed separately (Minton et al. 2011). The Penang population was not included in the statistical analysis, as the number of PI individuals is still very limited.

\section{India}

PI surveys were realized between November and April in 2004 to 2006 and in 2009 to 2011 in the Chilika Lagoon (Fig. 1), a large, brackish water body located in the Orissa region $\left(19^{\circ} 28^{\prime}\right.$ to $19^{\circ} 54^{\prime} \mathrm{N}$, $85^{\circ} 05^{\prime}$ to $85^{\circ} 38^{\prime} \mathrm{E}$ ). The lagoon water surface area varies from $1165 \mathrm{~km}^{2}$ in the monsoon season (June to September) to $906 \mathrm{~km}^{2}$ during the dry period (November to June). It is separated from the Bay of Bengal by an approximately $1.5 \mathrm{~km}$ wide and $60 \mathrm{~km}$ long sandy ridge. Surveys were carried out twice a month in the outer channel, in the central and southern sectors and in a dredged channel in the northern sector.

Whenever possible, both sides of the dorsal fin were photographed during the surveys, and each dolphin was assigned a single ID number (Sutaria \& Marsh 2011). Adults or sub-adults (distinguished by relative size) closely accompanying calves and juveniles were assumed to be females (Sutaria 2009).

\section{Bangladesh}

Line-transect surveys and other studies were realized in 2006 to 2010 in the waterways of the Sundarbans $\left(21^{\circ} 50^{\prime}\right.$ to $22^{\circ} 5^{\prime} \mathrm{N}, 89^{\circ} 00^{\prime}$ to $\left.90^{\circ} 00^{\prime} \mathrm{E}\right)$, very large contiguous mangrove forests, with an area of about $5770 \mathrm{~km}^{2}$ in the delta of the Bay of Bengal extending into India (Fig. 1). Large rivers enter the forest from the north and flow south and are laterally connected by numerous smaller channels that are home to an estimated 397 Orcaella brevirostris (Smith et al.
2006). Images of $O$. brevirostris were taken opportunistically while carrying out the surveys, mostly in the eastern half of the Bangladesh Sundarbans. As there was no dedicated effort to photo-identify the dolphins, the number of individuals examined for skin diseases is only approximate.

\section{Data collection and analysis}

Photo-catalogues were searched for skin disorders by the catalogue holders at each study site (Table 1). Images of suspected positive dolphins were extracted and further examined by the first author. They were rated for usefulness and quality according to characteristics, including distance from the photographer, angle and sharpness, and were classified into 3 categories: good, average and poor. While only good and average images were used to diagnose the presence of nodules on individuals at a particular stage during their lifespan, poor images were utilized to confirm the presence of noticeable lesions in successive years, if no better alternative photograph was available.

Whenever possible, the gross external characteristics of the disease, its progression (i.e. increase in nodule size and/or number in successive images of the same body area) and regression (i.e. decrease in the number and/or size of the lesions in successive images of the same body area) were investigated for each individual over the duration of the survey periods. The greatest diameter of the lesions was estimated photogrammetrically on the comparative basis of a mean dorsal fin height of $62 \mathrm{~mm}$ in Orcaella brevirostris (Beasley et al. 2005). Estimated lesion size was classified as small $(<7 \mathrm{~mm})$, medium-sized ( 7 to $15 \mathrm{~mm})$, or large (>15 mm).

Four skin nodules sampled in female KCH10-RDF035 (Kuching), which accidentally died in a gillnet on 10 August 2012, were measured, collected and preserved either in $95 \%$ ethanol or frozen at $-18^{\circ} \mathrm{C}$. Two lesions were routinely processed for histology, embedded in paraffin, sectioned at $5 \mu \mathrm{m}$ and stained with haematoxylin and eosin or Periodic Acid-Schiff.

\section{Epidemiology}

Prevalence of skin nodules in the communities was estimated as the ratio of the number of affected animals to the number of PI individuals. Prevalence levels should be considered as minima as, generally, only the upper body could be examined. Statistical significance of differences in prevalence between 
communities ( $\alpha=0.05$ level) was verified with a chisquared test. Prevalence of skin nodules in dolphins from eastern Malaysia was calculated separately for the right and left sides of the dorsal fin. Temporal variation in the prevalence of cutaneous nodules in Orcaella brevirostris from the Chilika Lagoon was examined with a McNemar's test using exact binomial probability calculations (www.vassarstats.net/ propcorr.html). We did not estimate prevalence levels for the dolphins of Penang and the Sundarbans, as PI studies in these areas are just beginning.
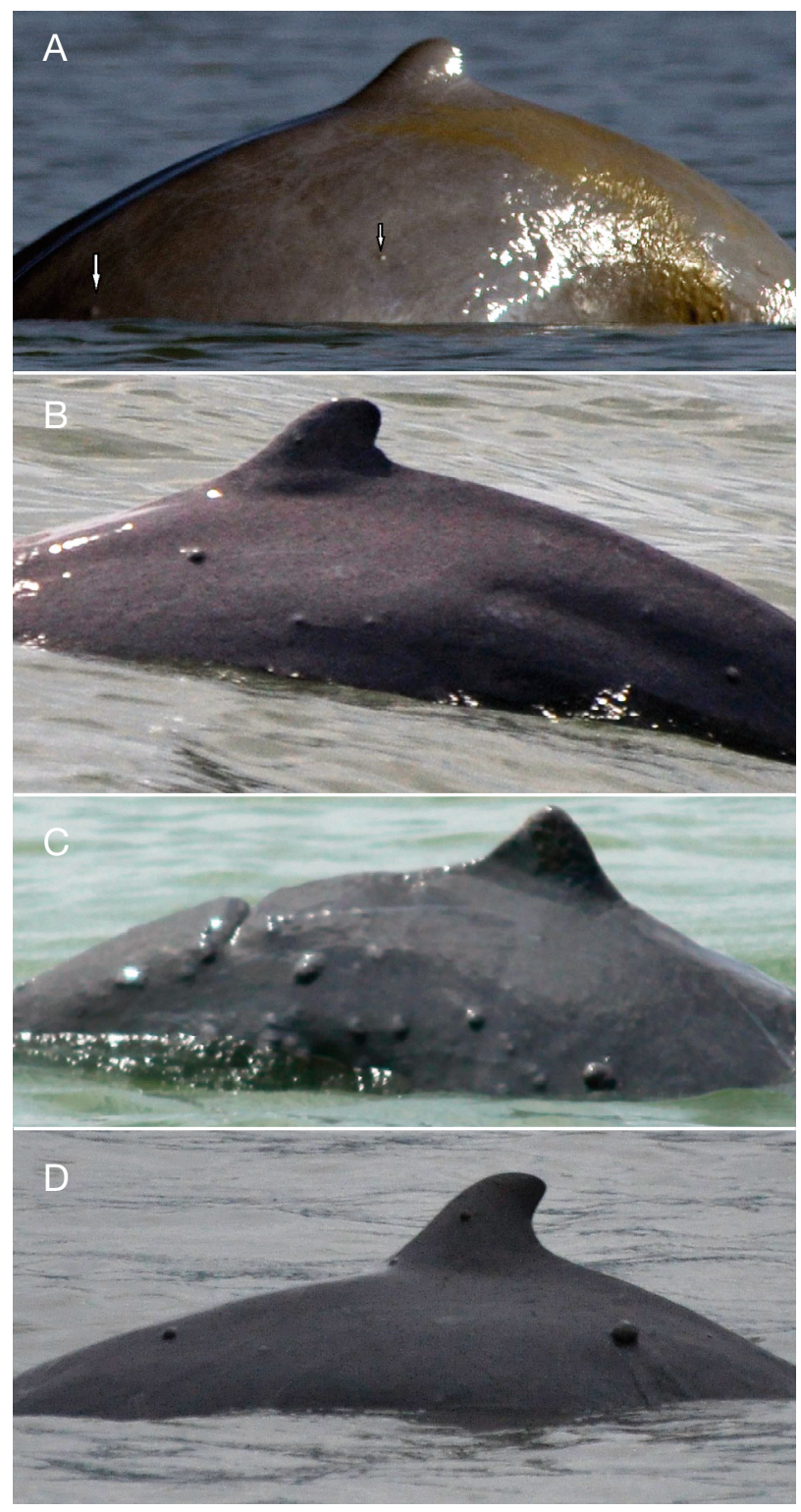

Fig. 2. Orcaella brevirostris. Small to large skin nodules in dolphins from (A) the Sundarbans, Bangladesh, in December 2006, ND2; and from Kuching, Malaysia: (B) KCH10RDF-035, August 2011, (C) KCH11-LDF-009/RDF-008, March 2011, and (D) KCH10-LDF-001, September 2011

\section{RESULTS}

We examined over 5700 images of Orcaella brevirostris photographed from 2004 to 2013 in 3 range states (Fig. 1). Skin nodules were detected in the 6 populations examined, with prevalence levels ranging from $2.2 \%(\mathrm{~N}=46$; Bintulu-Similajau) to $13.9 \%$ ( $\mathrm{N}=72$; Chilika Lagoon) in Malaysia and India (Table 1, Figs. $2 \& 3$ ). The earliest recognition of this condition dates back to January 2005. Characteristic tattoo skin disease (Geraci et al. 1979, Van Bressem et al. 2003) was not observed in these dolphins.

\section{Characteristics of the disease}

The cutaneous nodules appeared as circumscribed elevations of the skin, generally with a normal pigmentation and unbroken integument, and varied in size from 2 to $>30 \mathrm{~mm}$ at the widest point (Fig. 2). They were sparse (1 to 10$)$, or numerous $(>10)$, occurred on all visible body areas (dorsum, flanks, tailstock and dorsal fin) and were sometimes associated with wounds or scars (Table 1, Figs. 2 \& 3). The 2 index cases, A65 (Chilika Lagoon, India) and KCH11-LDF/009/RDF-008 (Sarawak, Malaysia), were the most extreme with $>30$ small to large cutaneous nodules on their visible body in 2009 and 2011, respectively (Figs. 2C \& 3B).

The evolution of the nodules could be evaluated in 8 PI dolphins from the Chilika Lagoon $(\mathrm{N}=2)$ and Sarawak $(\mathrm{N}=6)$ for which sequential images of the

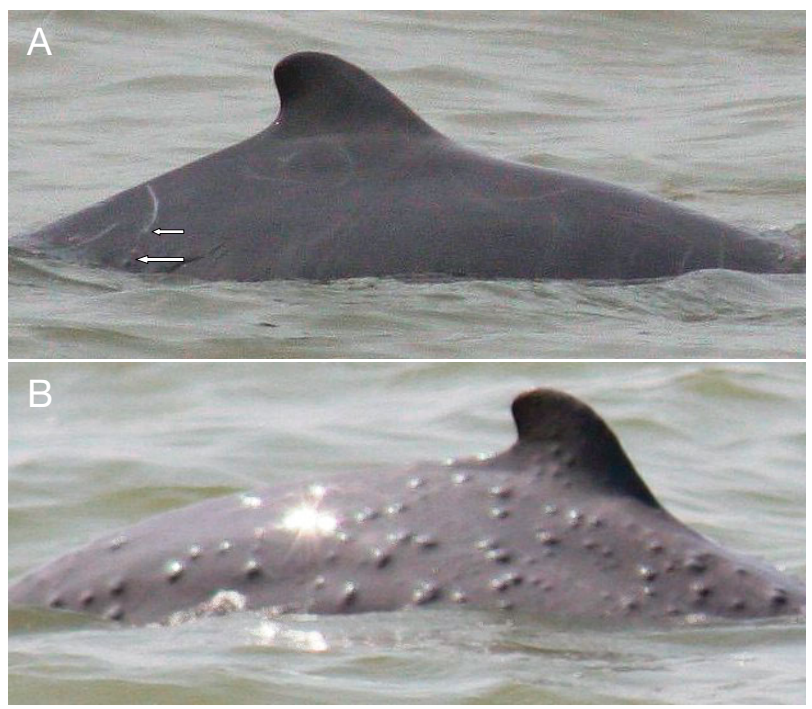

Fig. 3. Orcaella brevirostris. Progression of the skin disease in adult A65 from Chilika Lagoon, India, on (A) 28 January 2005 and (B) 5 February 2009 
same body area were available. Regression was not observed. In Sarawak, the disease remained stable in 2 dolphins and progressed in 4 other specimens over a time period of 4 to $24 \mathrm{mo}$. It also progressed in the 2 adult dolphins from Chilika (A65 and A1) during 49 and $61 \mathrm{mo}$, respectively (Table 1, Fig. 3). Frequently sighted in 2004 to 2006, the index case A65 had 3 small cutaneous nodules on its right flank in January 2005 (Fig. 3A). Numerous, small to medium lesions had developed on its dorsal fin, back and flank in February 2009 (Fig. 3B). The dolphin was again photographed in March 2009, but available images were too dark to assess disease evolution. It was not resighted in the period from April 2009 to December 2011, and its fate is unknown.

Histologically, the lesions sampled in female KCH10-RDF-035 (Fig. 2B) were non-encapsulated,

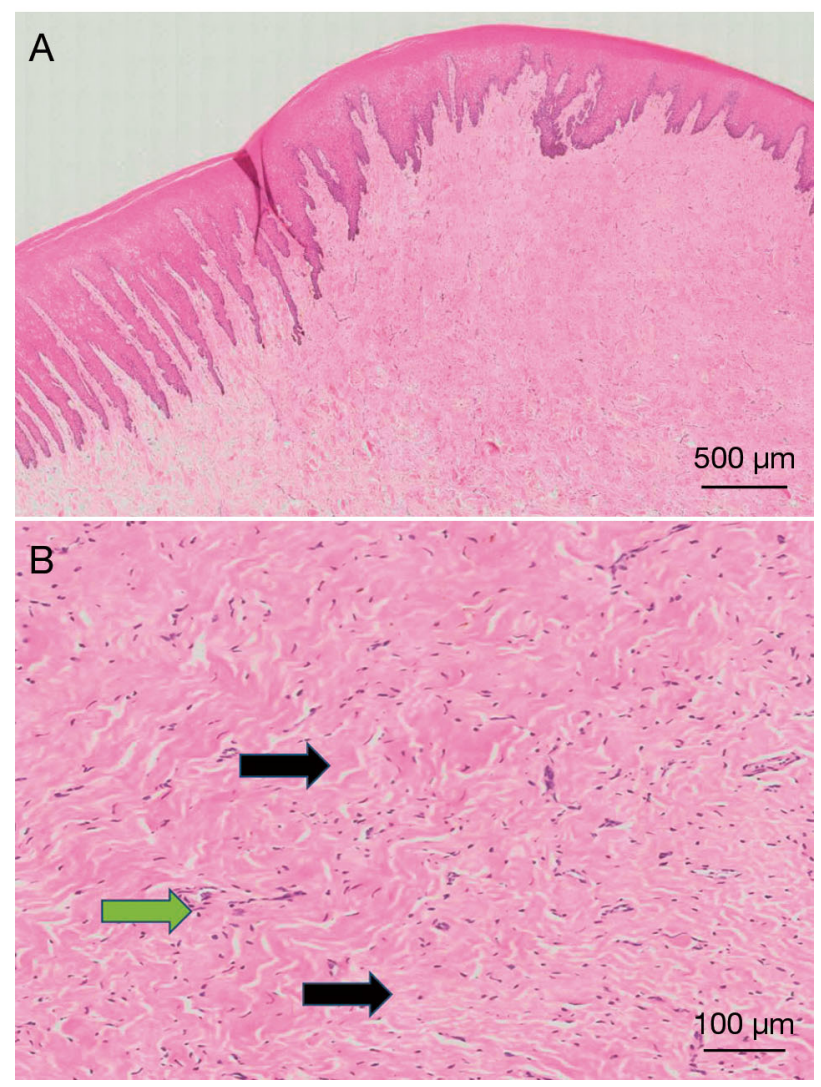

Fig. 4. Orcaella brevirostris. (A) Non-encapsulated, fairly circumscribed, raised nodular lesion involving the superficial dermis in female KCH10-RDF-035. The overlying epithelium is moderately hyperplasic; the rete pegs are irregular, shorter and larger than in the normal epithelium and extend into the dermis (haematoxylin and eosin). (B) Thick collagen bundles (black arrows) are present in the superficial dermis. There is a mild increase in cellularity and minimal perivascular inflammatory cells predominantly composed of mature lymphocytes (green arrow), (haematoxylin and eosin) fairly circumscribed, raised nodules involving the superficial dermis and formed by thick collagen bundles (Fig. 4). There was some moderate epithelial hyperplasia with hydropic degeneration in the stratum intermedium (Fig. 4A). The rete pegs were irregular, rounder, shorter and larger than in the normal epithelium and extended down into the dermis. There was also a mild increase in cellularity, with minimal perivascular inflammatory cells predominantly composed of mature lymphocytes (Fig. 4B). Special stain Periodic Acid Schiff for fungal bodies was negative. Areas of necrosis, atypical cells, increased mitosis, or malignant changes were not detected. The nodules were diagnosed as fibropapillomas following the nomenclature of Weedon (2002) and Schulman et al. (2003).

\section{Epidemiology \\ Malaysia}

Minimal prevalence levels varied between 2.2\% ( $\mathrm{N}=46$; Bintulu-Similajau) and 9.1\% ( $\mathrm{N}=11$; Kinabatangan) in the 3 Orcaella brevirostris populations from the states of Sabah and Sarawak in eastern Malaysia (Table 1). There was no significant difference in prevalence between the 3 sites using RDF $\left(\chi^{2}=1.45, \mathrm{df}=2, \mathrm{p}=0.48\right)$ or $\mathrm{LDF}\left(\chi^{2}=2.84, \mathrm{df}=2\right.$, $\mathrm{p}=0.24$ ) images. On Penang Island, 5 dolphins were found to have skin nodules (Table 1).

India

Minimum prevalence of skin nodules in Orcaella brevirostris from the Chilika Lagoon was $6.3 \%$ $(\mathrm{N}=80)$ in 2004 to 2006 and $13.9 \%(\mathrm{~N}=72)$ in 2009 to 2011. In 72 dolphins photo-identified during both periods, there were more new cases of infection $(\mathrm{N}=8)$ than cases of remission $(\mathrm{N}=0)$, and prevalence was significantly higher (McNemar test, $\mathrm{p}=$ 0.00078 ) in 2009 to 2011 (13.9\%) than in 2004 to 2006 $(2.8 \%)$. As the same photo-identification protocol was followed, with similar image quality and effort in image assessment during both periods, we believe that this result reflects a true tendency. Also, the stage with 'numerous nodules' was first observed only in the period from 2009 to 2011 (A65). All positive PI dolphins were adults; 5 were females and 8 were of unknown sex. Positive dolphins were observed in the outer channel $(\mathrm{n}=12)$ and in the southern sector $(\mathrm{N}=1)$ of the lagoon. 


\section{DISCUSSION}

This is the first report of a cutaneous disorder in freeranging, estuarine and riverine Orcaella brevirostris. Aside from a recent communication on bacterial infection in a specimen maintained in captivity in Beijing, China (Yu \& Xia 2013), there are, to our knowledge, no published papers on diseases in $O$. brevirostris.

Lesions sampled in a dead Orcaella brevirostris from Kuching had histological features consistent with fibropapillomas (fibroblastic proliferations with slight overlying epithelial hyperplasia; Schulman et al. 2003). It is possible that the nodules observed in the other $O$. brevirostris individuals were also fibropapillomas, as macroscopical features were identical (small to large, persistent cutaneous masses with a normal pigmentation and an intact overlying skin; Figs. 2 \& 3). However, this remains to be investigated. Other inflammatory, infectious, or neoplastic diseases can at this stage not be ruled out. Though genital, cutaneous and oral papillomas (localized epithelium hyperplasia with a defined boundary and an intact basement membrane; Shah \& Howley 1990) have been frequently described in odontocetes (Geraci et al. 1987, Lambertsen et al. 1987, Bossart et al. 1996, Van Bressem et al. 1996, 1999, 2007b, Rehtanz et al. 2006, Gottschling et al. 2011), to the best of our knowledge, there are no published papers on cutaneous fibropapillomas in these marine mammals. Often caused by viruses in the family Papillomaviridae, fibropapillomas are commonly diagnosed on the skin of many terrestrial mammals including deer, camels, horses and zebras ${ }^{1}$ where they can be plentiful and reach large sizes (Shope et al. 1958, Sundberg \& Nielsen 1981, Schulman et al. 2003, Nel et al. 2006). Whether papillomaviruses are implicated in the aetiology of fibropapillomas in $O$. brevirostris is possible, but requires further research. Proliferative fibropapillomas linked to herpesviruses plague marine turtles around the world, including along the coasts of Malaysia and Indonesia (Herbst 1994, Adnyana et al. 1997). However, the histology of the nodules sampled in dolphin KCH10-RDF-035 did not evoke herpesvirus infection. While not detected histologically in this study, other known aetiological agents of skin nodules in odontocetes include fungi (Lacazia loboi, Fusarium spp., Paracoccidioides brasiliensis and Trichophyton spp.) and the bacteria Streptococcus iniae (Caldwell et al. 1975, Frasca et al. 1996, Bonar \& Wagner 2003, Esperón et al. 2012, Tanaka et al. 2012).

\footnotetext{
${ }^{1}$ In horses and zebras fibropapillomas are referred to as sarcoids (Schulman et al. 2003)
}

Cutaneous nodules were encountered in all 6 Orcaella brevirostris populations examined in Malaysia, India and Bangladesh, with minimal prevalence levels varying between 2.2 and $13.9 \%$. In addition, they were also observed in the critically endangered sub-population from the Mahakam River, East Kalimantan, Indonesia (D. Kreb, pers. comm. to G. Minton and M.-F. Van Bressem on 17 May 2012). The most severe cases, as well as disease progression and increase in prevalence over time, were seen in Kuching and the Chilika Lagoon. Persistent organic pollutants were detected in $O$. brevirostris from the Chilika Lagoon in 2001 to 2002 (Kannan et al. 2005). By depressing the immune system these compounds increase the risk of infectious diseases in marine mammals (Aguilar \& Borrell 1994, Ross et al. 2000, Hall et al. 2006, Reif et al. 2009). Whether they are involved in boosting the development of cutaneous nodules in $O$. brevirostris is currently unknown.

During the present study, dolphin A65 (India), regularly sighted in 2004-2006, was re-photographed only once after becoming affected with generalized skin nodules in February 2009, and dolphin KCH11LDF-009/KCH11-RDF-008 (Malaysia) was never resighted after it was observed to have numerous cutaneous nodules in March 2011. However, because of the complex geographical features of the study areas and the elusive movements of the dolphins, it was not possible to determine whether the individuals had died, escaped detection when the surveys were conducted, or had moved out of the study areas. Interestingly, off the coast of Amakusa-Shimoshima Island, Japan, a resident mature male Indo-Pacific bottlenose dolphin Tursiops aduncus, regularly sighted since 1994, disappeared after having developed a high number of cutaneous nodules by July $2007^{2}$ (Van Bressem et al. 2013, M. Shirakihara and M. Nishita, pers. comm. to M.-F. Van Bressem in September 2013). Further PI studies are necessary to assess the impact of cutaneous nodules on the longterm health of affected Orcaella brevirostris.

The emergence of a novel disease in geographically distant, vulnerable and critically endangered Orcaella brevirostris populations, the progression in severity in some individuals and the increase in prevalence in dolphins from the Chilika Lagoon over years are of concern. Diseases are important factors in the decline of vulnerable and endangered species (Smith et al. 2009) and should be taken into account in action plans for the conservation of $O$. brevirostris.

\footnotetext{
${ }^{2}$ Photo-identification surveys in this area were conducted on a regular basis from 1994 to 2013
} 
Acknowledgements. Research in Sarawak was made possible through collaboration and permits from the Sarawak Forestry Department and Sarawak Forestry Corporation, as well as financial support from Sarawak Shell Berhad, the Ocean Park Conservation Foundation, the Malaysian Ministry of Science, Technology and Innovation and the Rio Tinto Corporation. The Kinabatangan Project was made possible through collaboration with the Sabah Forestry Department and was funded by LEAP (www.leapspiral.org), the Abraham Foundation and the Woodstiger Fund. The Penang project was supported by a short-term grant (304/ PPANTAI/6311103) from the University Sains Malaysia. Research in Chilika Lagoon was funded by James Cook University (Australia), the Ocean Park Conservation Foundation (Hong Kong) and the Wildlife Conservation Society (New York). We kindly thank Dr. D. Kreb for authorizing us to cite her data in the discussion, Dr. M. Shirakihara and M. Nishita for providing unpublished information, Dr. J. A. Aznar for his help with statistics, Dr. K. Van Waerebeek, Dr. P. Duignan and 2 anonymous reviewers for their useful comments on the manuscript, $\mathrm{Ng}$ Poh Pheng for preparing the histological specimens, Mr. Pratap Das for his assistance in the field, the Kinabatangan River people, the Orang Sungai, for permitting us to conduct research in their area and the research assistants from Balbhadrapura village (India) for helping with data collection.

\section{LITERATURE CITED}

Adnyana W, Ladds PW, Blair D (1997) Observations of fibropapillomatosis in green turtles (Chelonia mydas) in Indonesia. Aust Vet J 75:736-742

Aguilar A, Borrell A (1994) Abnormally high polychlorinated biphenyl levels in striped dolphins (Stenella coeruleoalba) affected by the 1990-1992 Mediterranean epizootic. Sci Total Environ 154:237-247

Baird IG, Beasley I (2005) Irrawaddy dolphin Orcaella brevirostris in the Cambodian Mekong River: an initial survey. Oryx 39:301-310

> Beasley I, Robertson KM, Arnold P (2005) Description of a new dolphin, the Australian snubfin dolphin Orcaella heinsohni sp n. (Cetacea, Delphinidae). Mar Mamm Sci 21:365-400

Bonar CJ, Wagner RA (2003) A third report of 'golf ball disease' in an Amazon River dolphin (Inia geoffrensis) associated with Streptococcus iniae. J Zoo Wildl Med 34: 296-301

Bossart GD, Cray C, Solorzano JL, Decker SI, Cornell LH, Altman NH (1996) Cutaneous papillonaviral-like papillomatosis in a killer whale (Orcinus orca). Mar Mamm Sci $12: 274-281$

Bossart GD, Meisner R, Varela R, Mazzoil M and others (2003) Pathologic findings in stranded Atlantic bottlenose dolphins (Tursiops truncatus) from the Indian River Lagoon, Florida. Fla Sci 66:226-238

Caldwell DK, Caldwell MC, Woodard JC, Ajello L, Kaplan W, McClure HM (1975) Lobomycosis as a disease of the Atlantic bottle-nosed dolphin (Tursiops truncatus Montagu, 1821). Am J Trop Med Hyg 24: 105-114

Daura-Jorge FG, Simões-Lopes PC (2011) Lobomycosis-like disease in wild bottlenose dolphins Tursiops truncatus of Laguna, southern Brazil: monitoring of a progressive case. Dis Aquat Org 93:163-170
Dolar MLL, Perrin WF, Gaudiano JP, Yaptinchay AASP, Tan JML (2002) Preliminary report on a small estuarine population of Irrawaddy dolphins (Orcaella brevirostris) in the Philippines. Raffles Bull Zool Suppl 10:155-160

> Esperón F, García-Párraga D, Bellière EN, Sánchez-Vizcaíno JM (2012) Molecular diagnosis of lobomycosis-like disease in a bottlenose dolphin in captivity. Med Mycol 50:106-109

> Frasca S Jr, Dunn JL, Cooke JC, Buck J (1996) Mycotic dermatitis in an Atlantic white-sided dolphin, a pygmy sperm whale, and two harbor seals. J Am Vet Med Assoc 208:727-729

> Geraci JR, Hicks BD, St Aubin DJ (1979) Dolphin pox: a skin disease of cetaceans. Can J Comp Med 43:399-404

> Geraci JR, Palmer NC, St Aubin DI (1987) Tumors in cetaceans: analysis and new findings. Can J Fish Aquat Sci 44: 1289-1300

> Gottschling M, Bravo IG, Schulz E, Bracho MA and others (2011) Modular organizations of novel cetacean papillomaviruses. Mol Phylogenet Evol 59:34-42

Gulland FM, Hall AJ (2007) Is marine mammal health deteriorating? Trends in the global reporting of marine mammal disease. EcoHealth 4:135-150

Hall AJ, Hugunin K, Deaville R, Law RJ, Allchin CR, Jepson PD (2006) The risk of infection from polychlorinated biphenyl exposure in the harbor porpoise (Phocoena phocoena): a case-control approach. Environ Health Perspect 114:704-711

Herbst LH (1994) Fibropapillomatosis of marine turtles. Annu Rev Fish Dis 4:389-425

IUCN (International Union for Conservation of Nature) (2008) Cetacean update of the 2008 IUCN Red List of threatened species. Available at: http://cmsdata.iucn. org/downloads/cetacean_table_for_website.pdf (accessed 14 June 2013)

Jefferson TA, Karczmarski L, Kreb D, Laidre K and others (2000) Orcaella brevirostris (Mahakam River subpopulation). In: IUCN 2012. IUCN Red List of threatened species, Version 2012.2. Available at: www.iucnredlist.org (accessed 20 May 2013)

Kannan K, Ramu K, Kajiwara N, Sinha RK, Tanabe S (2005) Organochlorine pesticides, polychlorinated biphenyls, and polybrominated diphenyl ethers in Irrawaddy dolphins from India. Arch Environ Contam Toxicol 49: 415-420

Kiszka J, Van Bressem MF, Pusineri C (2009) Lobomycosislike disease and other skin conditions in Indo-Pacific bottlenose dolphins Tursiops aduncus from the Indian Ocean. Dis Aquat Org 84:151-157

> Lambertsen RH, Kohn BA, Sundberg JP, Buergelt CD (1987) Genital papillomatosis in sperm whale bulls. J Wildl Dis 23:361-367

Minton G, Peter C, Tuen AA (2011) Distribution of small cetaceans in the nearshore waters of Sarawak, East Malaysia. Raffles Bull Zool 59:91-100

Minton G, Peter C, Zulkifli Poh AN, Ngeian J, Braulik G, Hammond PS, Tuen AA (2013) Population estimates and distribution patterns of Irrawaddy dolphins (Orcaella brevirostris) and Indo-Pacific finless porpoises (Neophocaena phocaenoides) in the Kuching Bay, Sarawak. Raffles Bull Zool 61:877-888

Murdoch ME, Mazzoil M, McCulloch S, Bechdel S, O'CorryCrowe G, Bossart GD, Reif JS (2010) Lacaziosis in bottlenose dolphins Tursiops truncatus along the coastal Atlantic Ocean, Florida, USA. Dis Aquat Org 92:69-73 
Nel PJ, Bertschinger H, Williams J, Thompson PN (2006) Descriptive study of an outbreak of equine sarcoid in a population of Cape mountain zebra (Equus zebra zebra) in the Gariep Nature Reserve. J S Afr Vet Assoc 77:184-190

Reeves RR, Smith BD, Crespo EA, Notarbartolo di Sciara G (2003) Dolphins, whales and porpoises: 2002-2010. Conservation action plan for the world's cetaceans. IUCN, Gland

Rehtanz M, Ghim SJ, Rector A, Van Ranst M, Fair PA, Bossart GD, Jenson AB (2006) Isolation and characterization of the first American bottlenose dolphin papillomavirus: Tursiops truncatus papillomavirus type 2. J Gen Virol 87:3559-3565

Reif JS, Peden-Adams MM, Romano TA, Rice CD, Fair PA, Bossart GD (2009) Immune dysfunction in Atlantic bottlenose dolphins (Tursiops truncatus) with lobomycosis. Med Mycol 47:125-135

Ross PSR, Vos JG, Birnbaum LS, Osterhaus ADME (2000) PCBs are a health risk for humans and wildlife. Science 289:1878-1879

Schulman FY, Krafft AE, Janczewski T, Reupert R, Jackson K, Garner MM (2003) Camelid mucoutaneous fibropapillomas: clinicopathologic findings and association with papillomavirus. Vet Pathol 40:103-107

Shah KV, Howley PM (1990) Papillomaviruses. In: Fields BN, Knippe DM, Channock RM, Hirsch MS, Monath TP, Roizman B (eds) Virology, 2nd edn. Raven Press, New York, NY, p 1651-1676

Shope RE, Mangold R, MacNamara LG, Dumbell KR (1958) An infectious cutaneous fibroma of the Virginia whitetailed deer (Odocoileus virginianus). J Exp Med 108: 797-802

Simões-Lopes PC, Paula GS, Xavier FM, Scaramelo AC (1993) First case of lobomycosis in bottlenose dolphin from Southern Brazil. Mar Mamm Sci 9:329-331

Smith BD (2009) Irrawaddy dolphin, Orcaella brevirostris. In: Perrin W, Wursig B, Thewissen JGM (eds) Encyclopedia of marine mammals. Elsevier, San Francisco, CA, p 638-642

Smith BD, Braulik G, Strindberg S, Ahmed B, Mansur R (2006) Abundance of Irrawaddy dolphins (Orcaella brevirostris) and Ganges river dolphins (Platanista gangetica gangetica) estimated using concurrent counts made by independent teams in waterways of the Sundarbans mangrove forest in Bangladesh. Mar Mamm Sci 22: 527-547

Smith BD, Ahmed B, Mowgli RM, Strindberg S (2008) Species occurrence and distributional ecology of nearshore cetaceans in the Bay of Bengal, Bangladesh, with abundance estimates for Irrawaddy dolphins Orcaella brevirostris and finless porpoises Neophocaena phocaenoides. J Cet Res Manag 101:45-58

Smith KF, Acevedo-Whitehouse K, Pedersen AB (2009) The role of infectious diseases on biodiversity. Anim Conserv 21:1-12

Sundberg JP, Nielsen SW (1981) Deer fibroma: a review. Can Vet J 22:385-388

Sutaria D (2009) Understanding species conservation in complex socio-ecological systems: case of Irrawaddy dol-

Editorial responsibility: Michael Moore,

Woods Hole, Massachusetts, USA phins in Chilika Lagoon, India. PhD dissertation, James Cook University, Townsville

Sutaria D, Marsh H (2011) Abundance estimates of Irrawaddy dolphins in Chilika Lagoon, India, using photo-identification based mark-recapture methods. Mar Mamm Sci 27:E338-E348

> Tanaka M, Izawa T, Kuwamura M, Nakao T and others (2012) Deep granulomatous dermatitis of the fin caused by Fusarium solani in a false killer whale (Pseudorca crassidens). J Vet Med Sci 74:779-782

Thompson PM, Hammond PS (1992) The use of photography to monitor dermal disease in wild bottlenose dolphins Tursiops truncatus. Ambio 21:135-137

Van Bressem MF, Van Waerebeek K, Piérard G, Desaintes C (1996) Genital and lingual warts in small cetaceans from coastal Peru. Dis Aquat Org 26:1-10

> Van Bressem MF, Kastelein RA, Flamant P, Orth G (1999) Cutaneous papillomavirus infection in a harbour porpoise (Phocoena phocoena) from the North Sea. Vet Rec 144:592-593

Van Bressem MF, Gaspar R, Aznar FJ (2003) Epidemiology of tattoo skin disease in bottlenose dolphins Tursiops truncatus from the Sado estuary, Portugal. Dis Aquat Org 56:171-179

> Van Bressem MF, Van Waerebeek K, Reyes JC, Félix F and others (2007a) A preliminary overview of skin and skeletal diseases and traumata in small cetaceans from South American waters. Lat Am J Aquat Mamm (LAJAM) 6: $7-42$

Van Bressem MF, Cassonnet P, Rector A, Desaintes C and others (2007b) Genital warts in Burmeister's porpoises: characterization of Phocoena spinipinnis papillomavirus type 1 (PsPV-1) and evidence for a second, distantly related PsPV. J Gen Virol 88:1928-1933

> Van Bressem MF, Raga JA, Di Guardo G, Jepson PD and others (2009a) Emerging infectious diseases in cetaceans worldwide and the possible role of environmental stressors. Dis Aquat Org 86:143-157

Van Bressem MF, Santos MC, Oshima JE (2009b) Skin diseases in Guiana dolphins (Sotalia guianensis) from the Paranaguá estuary, Brazil: a possible indicator of a compromised marine environment. Mar Environ Res 67: 63-68

Van Bressem MF, Shirakihara M, Masao A (2013) Cutaneous nodular disease in a small population of IndoPacific bottlenose dolphins, Tursiops aduncus, from Japan. Mar Mamm Sci 29:525-532

Van Waerebeek K, Baker AN, Felix F, Gedamke J and others (2008) Vessel collisions with small cetaceans worldwide and with large whales in the southern hemisphere, an initial assessment. Lat Am J Aquat Mamm; (LAJAM) 6:43-69

Weedon D (2002) Skin pathology, 2nd edn. Churchill Livingstone, London

Würsig B, Jefferson TA (1990) Methods of photo-identification for small cetaceans. Rep Int Whaling Comm Spec Issue 12:42-43

Yu JH, Xia ZF (2013) Bacterial infection in an Irrawaddy dolphin (Orcaella brevirostris). J Zoo Wildl Med 44:156-158

Submitted: July 1, 2013; Accepted: October 21, 2013

Proofs received from author(s): December 29, 2013 